\title{
Correlation between Electrical Resistivity and Cone Penetrometer Test Data for Geotechnical Site Investigation
}

\author{
${ }^{1 *}$ Akinlabi I. A. and ${ }^{2}$ Adeyemi G. O. \\ ${ }^{1}$ Department of Earth Sciences, Ladoke Akintola University of Technology, Ogbomoso, Nigeria. \\ ${ }^{2}$ Department of Geology, University of Ibadan, Ibadan, Nigeria. \\ *Corresponding Author E-mail: iaakinlabi@lautech.edu.ng Tel.: +2347060592144
}

Submitted on: 12/07/2021

Accepted on: $31 / 08 / 2021$

\begin{abstract}
The use of the electrical resistivity method provides cost-effective subsurface information faster and allows reliable interpolation to be made between the tested points. It is therefore desirable to generate consistent data from resistivity measurements by using empirical relationships while only few zones of interest will require testing. This study, therefore, developed empirical relationships between electrical resistivity sounding and cone penetrometer test data for engineering site investigation using a case study from the Basement Complex Terrain of Southwestern Nigeria. Regression analysis was used to assess the correlation between the soil resistivity and cone resistance and the validity of the empirical relation was evaluated by comparing values estimated from the soil resistivity vs. cone resistance cross plot with field values obtained from cone penetration tests. The values of allowable bearing pressure computed by using both values in Meyerhof's equation were also compared with the allowable bearing capacity deduced with laboratory values of soil strength parameters (cohesion, angle of internal friction, soil unit weight) in Terzaghi's general formula. The results show close agreement between the measured and estimated values with the differences typically less than 10\%. The standard errors of the estimates for the cone resistance and allowable bearing capacity are 2.70 and 4.16 respectively, implying reliability of the estimates. The proposed empirical relationships, therefore, appear to provide reasonable estimation of soil cone resistance and allowable bearing capacity from soil resistivity. Few complimentary cone penetrometer and laboratory tests will thus be required while the cost and duration of site investigation for engineering structures are expected to reduce.
\end{abstract}

Keywords: Cone resistance, Soil resistivity, Empirical relations, Site investigation, Allowable bearing capacity

\section{Introduction}

Dependable structural design for construction of engineering structures requires accurate evaluation of geotechnical properties of the subsoils meant to host the foundation at the proposed site (Cosenza et al., 2006; Gautam et al., 2007; Tempa and Chettri, 2020). The cone penetrometer test (CPT) is widely used in site investigation because it provides near-continuous information about soil properties with depth and can thus delineate discrete horizons that would normally be missed by using conventional subsurface sampling techniques (Akça, 2003; Ghose and Goudswaard, 2004; Eslami and Gholami, 2006; Kim et al., 2006; Mayne, 2007; Yi, 2014; Prasetya et al., 2017). It is capable of furnishing information on the density, consistency and shear strength of soil, for use in the design and construction of earthworks and foundations for structures.

The procedure of the test involves steadily pushing a 1.41-inch diameter $60^{\circ}$ cone into the ground from the surface at a constant rate of $1-2 \mathrm{~cm} / \mathrm{s}$ and the cone penetration resistance $\left(\mathrm{q}_{\mathrm{c}}\right)$ is measured and recorded continuously by load cells located just behind the tapered cone. The cone resistance is a direct indication of the strength of the soil at a given depth (Rogers, 2006; Robertson and Cabal, 2010; ASTM 3441, 2016). 
A series of empirical relations exist which allow direct calculation of allowable bearing pressure of soil from cone tip resistance (Meyerhof, 1965; Murthy, 2002). Undrained shear strength $\left(\mathrm{S}_{\mathrm{u}}\right)$ of saturated, cohesive material is theoretically related to cone resistance and can be reliably estimated from the latter where some basic information about some soil subsoil engineering properties are available (Rémai, 2013; Zein, 2017). Site investigation with CPT is, however, localized, invasive, time-consuming and expensive. In addition, boulders and significant amounts of gravel-sized particles and/or cemented sand can hinder or stop penetration and render the CPT data difficult to interpret quantitatively. The technique is thus most suitable for confirmation at critical points that have been previously identified.

Acquiring continuous electrical resistivity data is non-invasive, faster and cost-effective compared to other investigative techniques (Sharma, 2000). The method is used to investigate subsurface conditions by driving artificially-generated electric currents (I) into the ground through a pair of current electrodes and measuring the resulting potential differences $(\Delta \mathrm{V})$ across a pair of potential electrodes, at the surface. Deviations from the pattern of potential differences expected from homogeneous ground provide information on the form and electrical properties of subsurface inhomogeneity (Kearey et al., 2002).

The cone penetration test has been used in combination with electrical resistivity method to obtain subsurface information for foundation investigation (Oyedele and Olorode, 2010; Adebisi and Fatoba, 2013; Adeoti et al., 2016; Adewoyin et al., 2017; Coker et al., 2017). However, the studies did not propose empirical relationship between resistivity and cone resistance with a view to deducing the latter for cost effective, non-invasive and time-saving engineering site investigation. Published works that relate electrical resistivity with CPT data are therefore rare.

Endres and Clement (1998) observed a relationship between soil types determined from mechanical properties measured by cone penetrometer tests (CPT) and electrical properties by using semi-logarithmic crossplots of dielectric permittivity versus electrical resistivity. The analysis revealed that CPT soil types cluster in a systematic manner to form a linear trend from clay-prone to sand-prone lithologies. Segregation of the soil types improved when other factors such as location to the water table, and stratigraphy were used to refine the data analysis. The results also indicated that the ratio of dielectric permittivity to logarithm of electrical resistivity is a good discriminator of soil type. Cosenza et al. (2006) obtained no clear quantitative relationship between cone resistance and inverted resistivity extracted from electrical resistivity sections at Garchy (Nièvre, France) in the southeastern part of the sedimentary basin of Paris. They, however, observed that the inverted resistivity-cone resistance crossplot would discriminate lithology when the upper sandy soil composed of gravel was excluded and the inverted resistivity values obtained from extracted 1D sounding were considered.

Since attempts to relate electrical resistivity with cone penetrometer test data are rare, it is imperative to establish the empirical relationships between both parameters so that the latter can be estimated from the less expensive and faster resistivity data in foundation studies for engineering structures. Fewer CPTs and laboratory tests will thus be required while the cost and duration of site investigations for engineering structures are reduced. The aim of this study, therefore, is to employ electrical resistivity and cone penetrometer test data to investigate subsurface properties and establish empirical relationships between the electrical resistivity and cone resistance of the subsoil, which is the soil resistance to load.

The study area is located between the geographic coordinates: Longitude $04^{\circ} 27.072^{\prime} \mathrm{E}-04^{\circ} 27.233^{\prime} \mathrm{E}$ and Latitude $07^{\circ} 33.107^{\prime} \mathrm{N}-07^{\circ} 33.548^{\prime} \mathrm{N}$ northwest of Ile-Ife, on Iwo Sheet $242 \mathrm{~S}$.E. It is underlain by the Precambrian Basement Complex rocks of southwestern Nigeria (Rahaman, 1989). The predominant rock type is hornblende biotite gneiss. The rock is generally dark-grey in colour and has texture varying from fine to medium to coarse, planar fabric and very good foliation planes. 
LAUTECH Journal of Civil and Environmental Studies

Volume 7, Issue 1; September, 2021

Materials and Methods

Schlumberger vertical electrical sounding was conducted at twenty-six points to determine the soil resistivity (Figure 1). The current electrode spacing $(\mathrm{AB} / 2)$ was varied from $1 \mathrm{~m}$ to $100 \mathrm{~m}$. The VES data were quantitatively interpreted using initial partial curve matching in which the field curves were superimposed on two-layer master curves and their corresponding auxiliary curves to obtain the starting model parameters comprising resistivities and thicknesses. The layer parameters were then used as input for forward modeling technique, in WinRESIST Version 1.0, to determine the layer parameters (VanderVelpen, 2004).

Cone Penetration Test (CPT) was conducted at twenty-six points to determine the resistance of the earth to cone tip penetration in accordance with ASTM Standard D3441 (2016). The cone resistances were measured and recorded $\left(\right.$ in $\mathrm{kg} / \mathrm{cm}^{2}$ ) at $0.25 \mathrm{~m}$ intervals as the CPT instrument (2.5-tonne Dutch Cone Penetrometer) was advanced through the ground up to practical refusal. The CPTs were conducted close to the VES points to allow correlation with geoelectric data (Figure 1). The values of cone resistance $\left(\mathrm{q}_{\mathrm{c}}\right)$ were plotted against penetration depths to produce the CPT plots while mathematical relationships were established between the resistivity and CPT data.

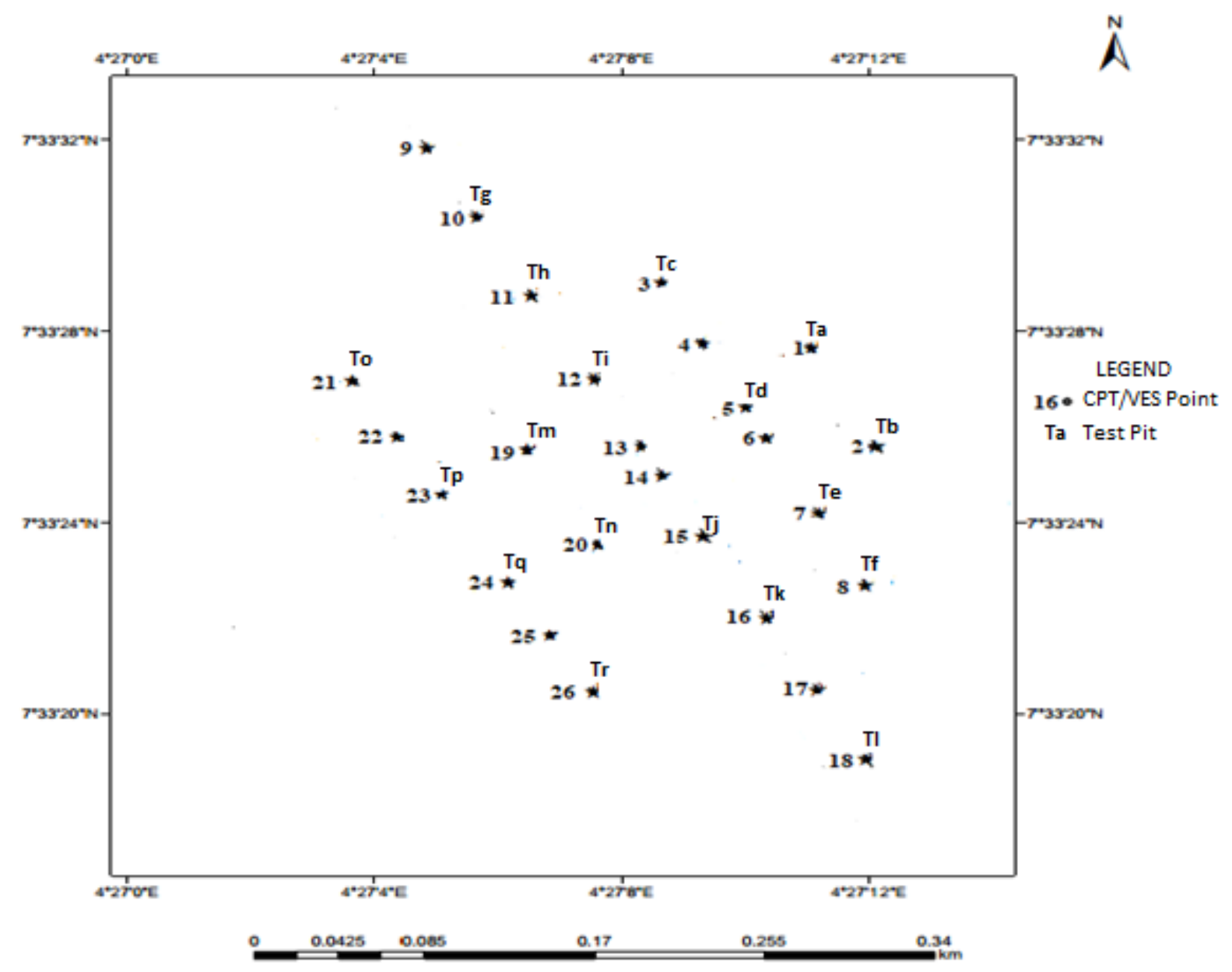

Figure 1: VES, CPT and sampling points at the study location. 
Regression analysis was carried out to obtain the coefficient of correlation and the empirical equations were validated by determining the percentage errors and error of the estimates between the estimated and the field/measured values of the cone resistance. Values of allowable bearing pressure, $\mathrm{q}_{\mathrm{a}}$ were computed from Meyerhof formula (1956):

$$
\mathrm{q}_{\mathrm{a}}=2.7 \mathrm{q}_{\mathrm{c}}
$$

where $\mathrm{q}_{\mathrm{c}}$ is the cone resistance, and allowable bearing capacity determined after dividing ultimate bearing capacity:

$$
\mathrm{q}_{\mathrm{u}}=0.5 \gamma \mathrm{BN}_{\gamma}+\mathrm{cN}_{\mathrm{c}}+\gamma \mathrm{DN}_{\mathrm{q}}
$$

obtained from Terzaghi's general formula (1967) for strip footing by a safety factor of 3 . The strength parameters $\mathrm{c}$ and $\varnothing$ are the soil cohesion $\left(\mathrm{kN} / \mathrm{m}^{2}\right)$ and angle of internal friction

respectively, obtained from Quick undrained triaxial compression test conducted on undisturbed soils sampled test pits dug at points coincident with the CPT and VES points, at depths corresponding to the CPT refusal. $B=$ width of the footing $(\mathrm{m}), \mathrm{D}=$ depth of foundation $(\mathrm{m}) \gamma=$ soil unit weight $\left(\mathrm{kN} / \mathrm{m}^{3}\right), \mathrm{q}_{\mathrm{u}}=$ ultimate bearing capacity $\left(\mathrm{kN} / \mathrm{m}^{2}\right)$ while $\mathrm{N}_{\gamma}, \mathrm{N}_{\mathrm{c}}, \mathrm{N}_{\mathrm{q}}$ are bearing capacity factors, which are functions of soil friction angle (Bowles, 1997). The values of ultimate bearing pressure were computed with $\mathrm{D}=1.0$ to $2.5 \mathrm{~m}$ and $\mathrm{B}$ $=1.2 \mathrm{~m}$ within the range for shallow foundation (Waheed and Asmael, 2018). The estimated bearing pressure values were subjected to validity tests by comparing with those obtained from field measurement of soil strength parameters and laboratory analyses.

\section{Results and Discussion}

Results of VES reveal a three-layer model representing topsoil, saprolite and bedrock. Resistivity and thickness of the topsoil range from $40 \Omega \mathrm{m}$ to $1260 \Omega \mathrm{m}$ and $0.2 \mathrm{~m}$ to $1.6 \mathrm{~m}$ respectively. The saprolite has resistivity ranging from $15 \Omega \mathrm{m}$ to $643 \Omega \mathrm{m}$ and is $0.3 \mathrm{~m}$ to $8.0 \mathrm{~m}$ thick. Bedrock resistivity ranges from 980 $\Omega \mathrm{m}$ to $25762 \Omega \mathrm{m}$ while depth to the bedrock varies from $1.6 \mathrm{~m}$ to $9.2 \mathrm{~m}$. The results of Cone Penetration Tests conducted presented in Tables 1 ( $a$ and b) show cone tip resistance, $\mathrm{q}_{\mathrm{c}}$ ranging from 85 to $180 \mathrm{~kg} / \mathrm{cm}^{2}$ indicating a wide range of soil consistency across the study area. The values generally increase with depth while refusal to cone tip occurred at depths ranging from $1.0 \mathrm{~m}$ to $2.5 \mathrm{~m}$. Figure 2 show typical cone resistance vs depth plots and CPT-VES log obtained for the study area respectively. There is strong correlation between the depths to the topsoil-saprolite interface determined by interpretation of the resistivity data and those obtained by CPT Field measurements (Figure 3). The coefficient of correlation, $\mathrm{R}$ is 0.79 .

Table 1a: Cone tip resistance at $\mathrm{C} 1-\mathrm{C} 13$

\begin{tabular}{lllllllllllllll}
\hline $\begin{array}{l}\text { Depth } \\
(\mathrm{m})\end{array}$ & \multicolumn{11}{c}{ Cone tip resistance, $\mathrm{q}_{\mathrm{c}}\left(\mathrm{kg} / \mathrm{cm}^{2}\right)$} \\
\hline & $\mathrm{C} 1$ & $\mathrm{C} 2$ & $\mathrm{C} 3$ & $\mathrm{C} 4$ & $\mathrm{C} 5$ & $\mathrm{C} 6$ & $\mathrm{C} 7$ & $\mathrm{C} 8$ & $\mathrm{C} 9$ & $\mathrm{C} 10$ & $\mathrm{C} 11$ & $\mathrm{C} 12$ & $\mathrm{C} 13$ \\
\hline 0.25 & 10 & 10 & 20 & 75 & 3 & 5 & 5 & 4 & 8 & 5 & 8 & 7 & 6 \\
0.50 & 15 & 20 & 35 & 50 & 6 & 8 & 11 & 8 & 15 & 11 & 15 & 20 & 10 \\
0.75 & 30 & 35 & 25 & 45 & 10 & 15 & 30 & 15 & 45 & 25 & 45 & 40 & 15 \\
1.00 & 40 & 15 & 75 & 100 & 10 & 21 & 30 & 55 & 165 & 20 & 73 & 50 & 10 \\
1.25 & 85 & 20 & 50 & 60 & 15 & 40 & 4 & 87 & - & 47 & 100 & 40 & 20 \\
1.50 & 110 & 40 & 100 & 100 & 40 & 65 & 5 & 96 & - & 69 & 111 & 115 & 40 \\
1.75 & - & 78 & - & 145 & 100 & 80 & 50 & 110 & - & 98 & 180 & - & 75 \\
2.00 & - & 110 & - & - & 110 & 110 & 75 & - & - & 110 & - & - & 145 \\
2.25 & - & 115 & - & - & 125 & 115 & 100 & - & - & - & - & - & - \\
2.50 & - & 125 & - & - & 125 & 125 & 110 & - & - & - & - & - & - \\
\hline
\end{tabular}


LAUTECH Journal of Civil and Environmental Studies

Volume 7, Issue 1; September, 2021

Table 1b: Cone tip resistance at $\mathrm{C} 13-\mathrm{C} 26$

\begin{tabular}{llllllllllllll}
\hline $\begin{array}{l}\text { Depth } \\
(\mathrm{m})\end{array}$ & \multicolumn{110}{c}{ Cone tip resistance, $\mathrm{q}_{\mathrm{c}}\left(\mathrm{kg} / \mathrm{cm}^{2}\right)$} \\
\hline 0.25 & 15 & 10 & 1 & 1 & 10 & 15 & 15 & 10 & 15 & 25 & 8 & 15 & 80 \\
0.50 & 20 & 20 & 10 & 3 & 8 & 20 & 21 & 26 & 36 & 137 & 20 & 15 & 35 \\
0.75 & 35 & 35 & 3 & 6 & 10 & 18 & 40 & 48 & 50 & - & 35 & 10 & 55 \\
1.00 & 20 & 35 & 20 & 10 & 15 & 40 & 52 & 60 & 75 & - & 40 & 15 & 132 \\
1.25 & 30 & 40 & 120 & 10 & 25 & 65 & 90 & 83 & 100 & - & 50 & 40 & - \\
1.50 & 45 & 100 & - & 45 & 40 & 100 & 152 & 115 & 110 & - & 65 & 78 & - \\
1.75 & 35 & 100 & - & 75 & 65 & - & 170 & 110 & - & - & 85 & 98 & - \\
2.00 & 55 & - & - & 98 & 100 & - & 130 & - & - & - & 120 & 126 & - \\
2.25 & 85 & - & - & 110 & - & - & - & - & - & - & - & - & - \\
2.50 & 145 & - & - & 125 & - & - & - & - & - & - & - & - & - \\
\hline
\end{tabular}

The measured cone resistance, $q_{c}$ shows direct relation with subsoil resistivity, $\rho$ in the study area (Figure 4). The empirical equation is: $q_{c}=0.084 \rho+111.28$ with coefficient of correlation, $R=0.84$, indicating very strong relationship (Evans, 1996). The result suggests that soil cone resistance can be reliably estimated by using soil resistivity obtained from inversion of vertical electrical sounding data. The values of cone resistance estimated using the empirical equation $\left(\mathrm{q}_{\mathrm{cp}}\right)$ and those measured $\left(\mathrm{q}_{\mathrm{cm}}\right)$ from field cone penetrometer test are presented in Table 2. The differences between the measured cone resistance values and those estimated from the resistivity vs. cone resistance curve are typically less than $10 \%$ suggesting that the empirical equation would yield cone resistance values in good agreement with the measured values.

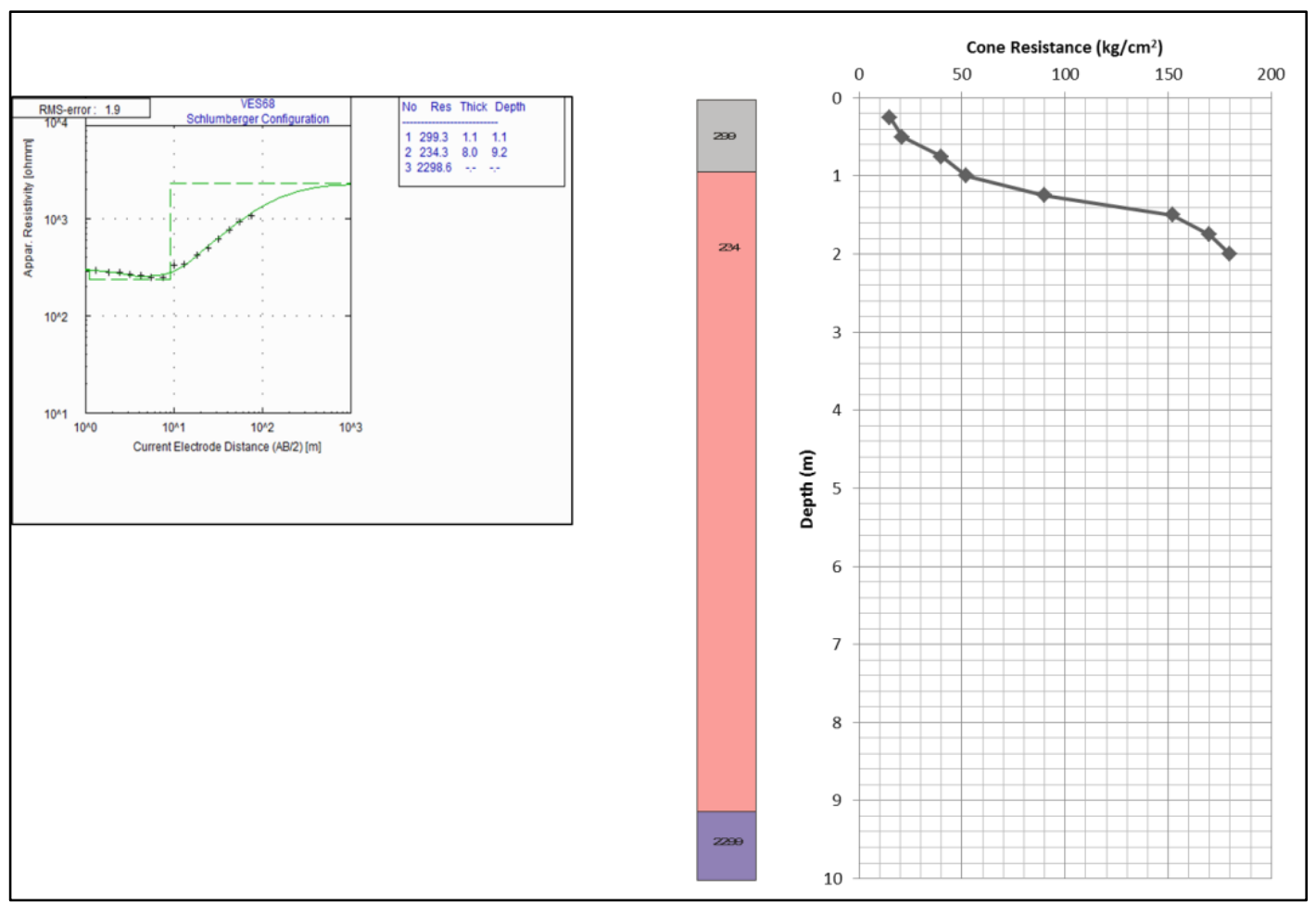

Figure 2: Typical CPT-VES log obtained from the study area 


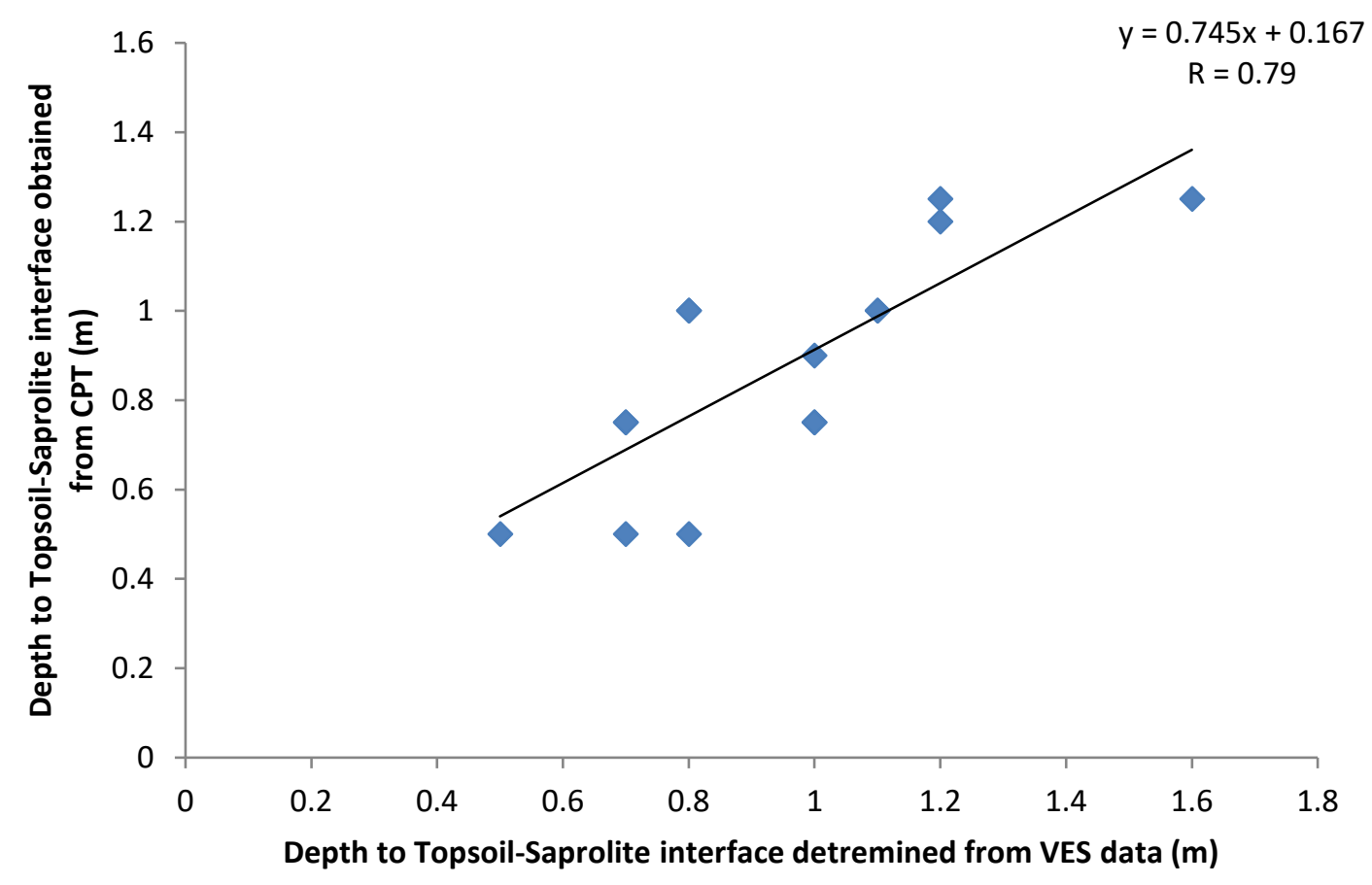

Figure 3: Comparison of depth to the topsoil-saprolite interface determined from sounding data with those obtained from cone penetrometer test

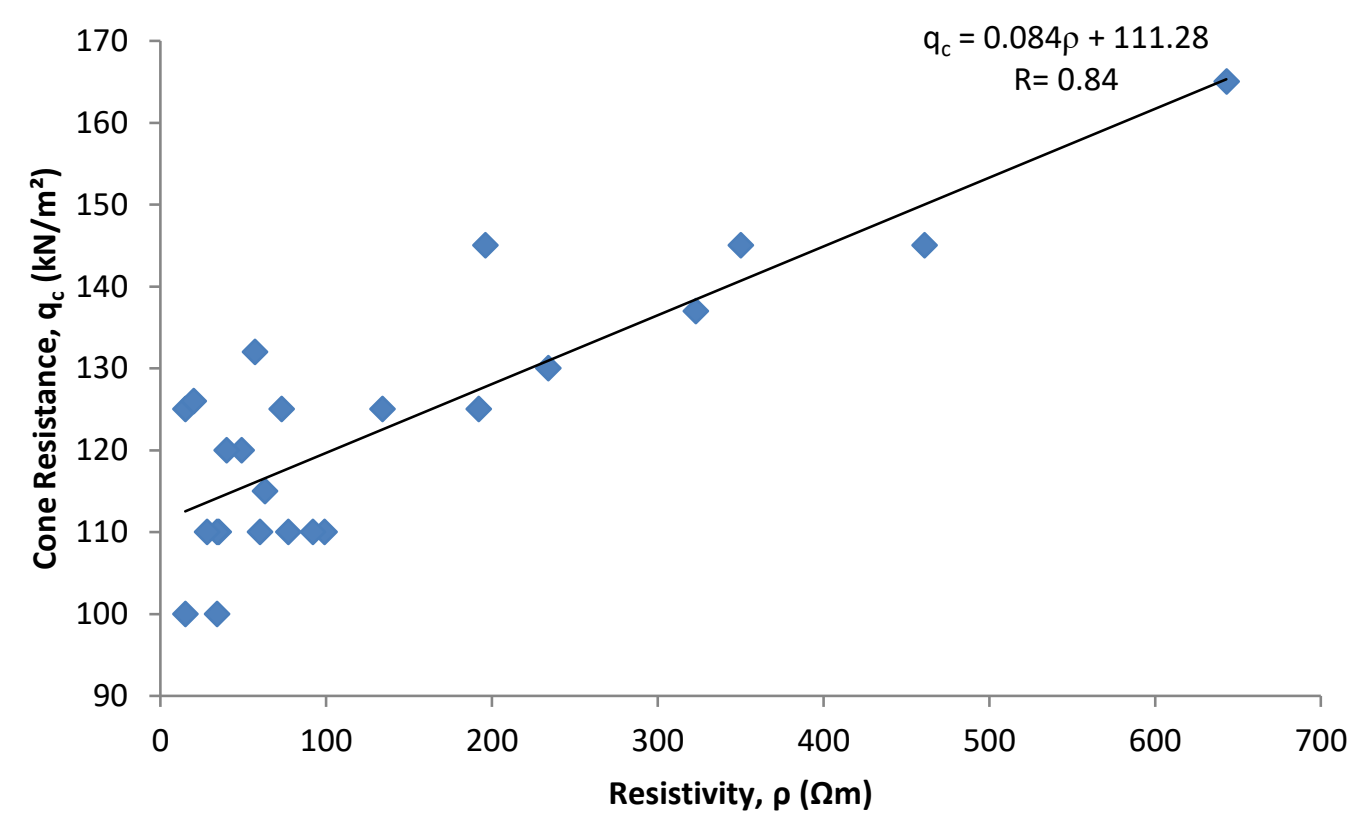

Figure 4: Cone resistance vs inverted resistivity obtained from 1D resistivity sounding in the study area 
LAUTECH Journal of Civil and Environmental Studies

Volume 7, Issue 1; September, 2021

Table 2: Comparison of measured with estimated values of cone resistance

\begin{tabular}{ccccc}
\hline CPT/VES & $\begin{array}{c}\text { Resistivity, } \\
\rho(\Omega \mathrm{m})\end{array}$ & $\begin{array}{c}\text { Measured Cone resistance } \\
\left(\mathrm{kg} / \mathrm{cm}^{2}\right)\end{array}$ & $\begin{array}{c}\text { Estimated Cone resistance } \\
\left(\mathrm{kg} / \mathrm{cm}^{2}\right)\end{array}$ & \% Error \\
\hline $\mathbf{1}$ & 77 & 110 & 118 & 6.8 \\
$\mathbf{2}$ & 15 & 125 & 113 & 10.6 \\
$\mathbf{3}$ & 34 & 100 & 114 & 13.3 \\
$\mathbf{4}$ & 196 & 145 & 128 & 1.6 \\
$\mathbf{5}$ & 134 & 125 & 123 & 1.6 \\
$\mathbf{6}$ & 192 & 125 & 127 & 3.5 \\
$\mathbf{7}$ & 35 & 110 & 114 & 5.2 \\
$\mathbf{8}$ & 60 & 110 & 116 & 0.6 \\
$\mathbf{9}$ & 643 & 165 & 166 & 8.3 \\
$\mathbf{1 0}$ & 99 & 110 & 120 & 7.2 \\
$\mathbf{1 1}$ & 976 & 180 & 194 & 1.7 \\
$\mathbf{1 2}$ & 63 & 115 & 117 & 2.8 \\
$\mathbf{1 3}$ & 350 & 145 & 141 & 3.3 \\
$\mathbf{1 4}$ & 461 & 145 & 150 & 3.5 \\
$\mathbf{1 5}$ & 34 & 110 & 114 & 4.4 \\
$\mathbf{1 6}$ & 49 & 120 & 115 & 6.8 \\
$\mathbf{1 7}$ & 73 & 125 & 117 & 9.9 \\
$\mathbf{1 8}$ & 56 & 100 & 111 & 11.5 \\
$\mathbf{1 9}$ & 15 & 100 & 113 & 0.8 \\
$\mathbf{2 0}$ & 234 & 130 & 131 & 3.5 \\
$\mathbf{2 1}$ & 28 & 110 & 114 & 7.6 \\
$\mathbf{2 2}$ & 92 & 110 & 119 & 0.7 \\
$\mathbf{2 3}$ & 323 & 137 & 138 & 4.4 \\
$\mathbf{2 4}$ & 40 & 120 & 115 & 13.5 \\
$\mathbf{2 5}$ & 20 & 126 & 113 & 1.5 \\
$\mathbf{2 6}$ & 57 & 132 & 116 & \\
\hline
\end{tabular}

The measured $\left(\mathrm{q}_{\mathrm{cm}}\right)$ and estimated (qce) values correlate very strongly with $\mathrm{R}=0.84$ (Figure 5) while the standard error of the estimates is 2.70 . The standard error of the estimates indicates the approximate error that is made when the cone resistance is estimated by using the empirical equation.

The values of allowable bearing pressure $\left(\mathrm{q}_{\mathrm{a}}\right)$ computed with the estimated cone resistance in the empirical equation: $\mathrm{q}_{\mathrm{a}}=2.7 \mathrm{q}_{\mathrm{c}}$ (Meyerhof, 1956) range from 230 to $392 \mathrm{kPa}$ suggestive of very stiff clay (BS 8004, 2015; Craig, 2004). The allowable bearing capacity ( $\left.\mathrm{q}_{\mathrm{s}}\right)$ determined after applying Factor of safety of 3 to the Ultimate bearing capacity ( $\mathrm{q}_{\mathrm{u}}$ ) obtained from Terzaghi's general formula (1967) with values of soil cohesion, c, and angle of internal friction, $\varnothing$, ranges from 279 to $399 \mathrm{kPa}$ (Table 3). The allowable bearing pressure estimated from the empirical equation relating soil resistivity and cone resistance is in close agreement with the values computed from field measurements using the Terzaghi and Meyerhof formulae (Figure 6). The \% Error is less than 10\% while the standard error of the estimates of 4.16 being the approximate error that is made when allowable bearing pressure is estimated by using the cone resistance deduced from the empirical relation.

Reliable estimation of allowable bearing pressure from empirical relations will reduce the amount of field and laboratory tests required to acquire geotechnical parameters for time-saving and economic foundation design. The allowable bearing pressure of a soil is its ability to carry the load of a structure without shear failure or excessive settlement 


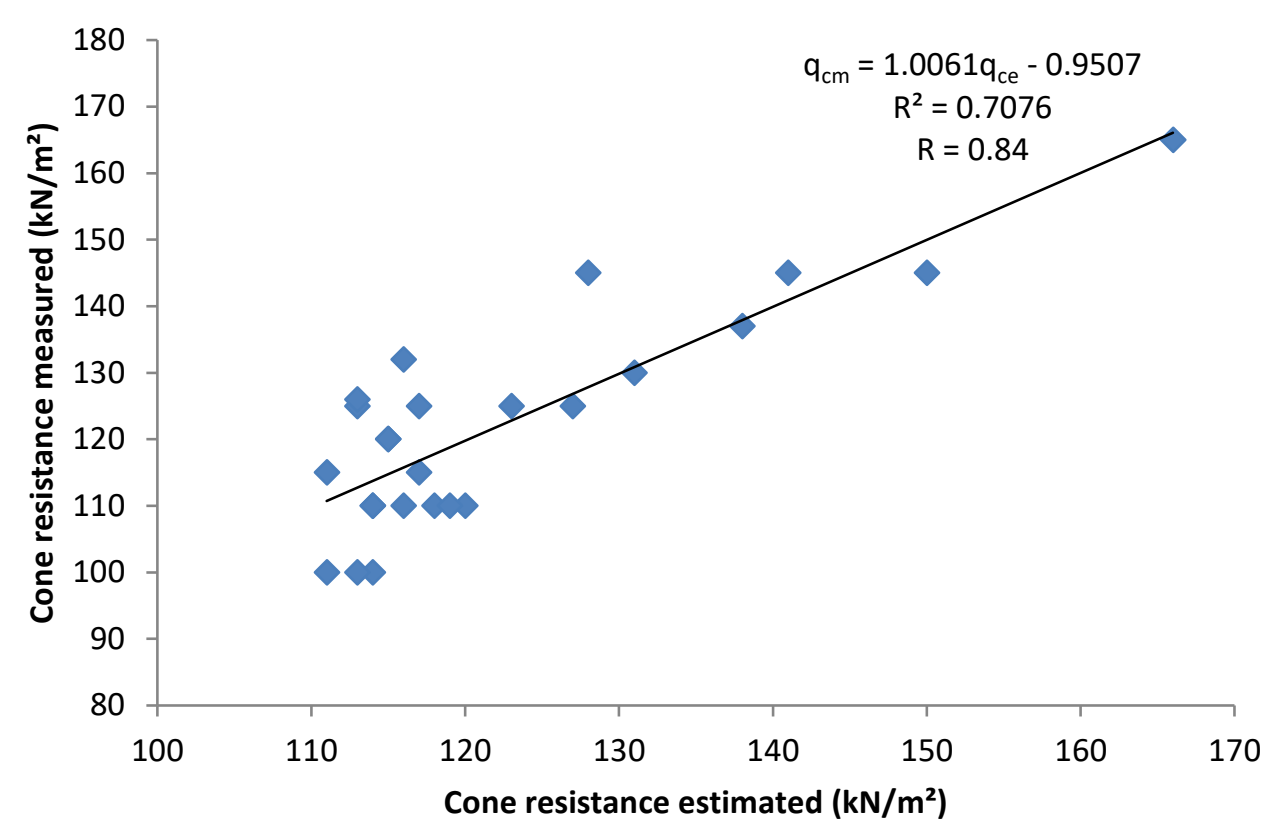

Figure 5: Correlation between measured and estimated cone resistance

Table 3: Allowable Bearing Capacity $\left(\mathrm{q}_{\mathrm{s}}\right)$ determined using Terzaghi's General Formula and Allowable Bearing Pressure $\left(\mathrm{q}_{\mathrm{a}}\right)$ obtained using estimated cone resistance in Meyerhof Equation

\begin{tabular}{lllllll}
\hline Sample & $\mathrm{c}\left(\mathrm{kN} / \mathrm{m}^{2}\right)$ & $\emptyset($ degrees $)$ & $\gamma\left(\mathrm{kN} / \mathrm{m}^{3}\right)$ & $\mathrm{qu}_{\mathrm{u}}\left(\mathrm{kN} / \mathrm{m}^{2}\right)$ & $\mathrm{q}_{\mathrm{s}}\left(\mathrm{kN} / \mathrm{m}^{2}\right)$ & $\mathrm{q}_{\mathrm{a}}\left(\mathrm{kN} / \mathrm{m}^{2}\right)$ \\
\hline $\mathrm{T}_{\mathrm{a}}$ & 22 & 27 & 14.7 & 916 & 305 & 318 \\
$\mathrm{~T}_{\mathrm{b}}$ & 32 & 22 & 15.6 & 892 & 297 & 304 \\
$\mathrm{~T}_{\mathrm{c}}$ & 22 & 26 & 14.7 & 837 & 279 & 308 \\
$\mathrm{~T}_{\mathrm{d}}$ & 23 & 27 & 14.4 & 979 & 326 & 345 \\
$\mathrm{~T}_{\mathrm{e}}$ & 32 & 24 & 14.2 & 1017 & 339 & 331 \\
$\mathrm{~T}_{\mathrm{f}}$ & 20 & 26 & 15.5 & 996 & 332 & 344 \\
$\mathrm{~T}_{\mathrm{g}}$ & 30 & 22 & 15.3 & 852 & 284 & 308 \\
$\mathrm{~T}_{\mathrm{h}}$ & 34 & 23 & 16.0 & 911 & 304 & 314 \\
$\mathrm{~T}_{\mathrm{i}}$ & 44 & 26 & 14.2 & 1231 & 410 & 446 \\
$\mathrm{~T}_{\mathrm{j}}$ & 26 & 25 & 13.5 & 893 & 298 & 323 \\
$\mathrm{~T}_{\mathrm{k}}$ & 40 & 28 & 14.3 & 1512 & 504 & 523 \\
$\mathrm{~T}_{\mathrm{l}}$ & 28 & 25 & 15.9 & 912 & 304 & 315 \\
$\mathrm{~T}_{\mathrm{m}}$ & 27 & 27 & 14.0 & 1110 & 370 & 380 \\
$\mathrm{~T}_{\mathrm{n}}$ & 6 & 31 & 15.6 & 1198 & 399 & 405 \\
$\mathrm{~T}_{\mathrm{o}}$ & 28 & 24 & 16.2 & 880 & 293 & 308 \\
$\mathrm{~T}_{\mathrm{p}}$ & 40 & 22 & 1.61 & 881 & 294 & 312 \\
$\mathrm{~T}_{\mathrm{q}}$ & 26 & 23 & 15.8 & 865 & 289 & 317 \\
$\mathrm{~T}_{\mathrm{r}}$ & 26 & 24 & 15.9 & 873 & 291 & 313 \\
\hline
\end{tabular}




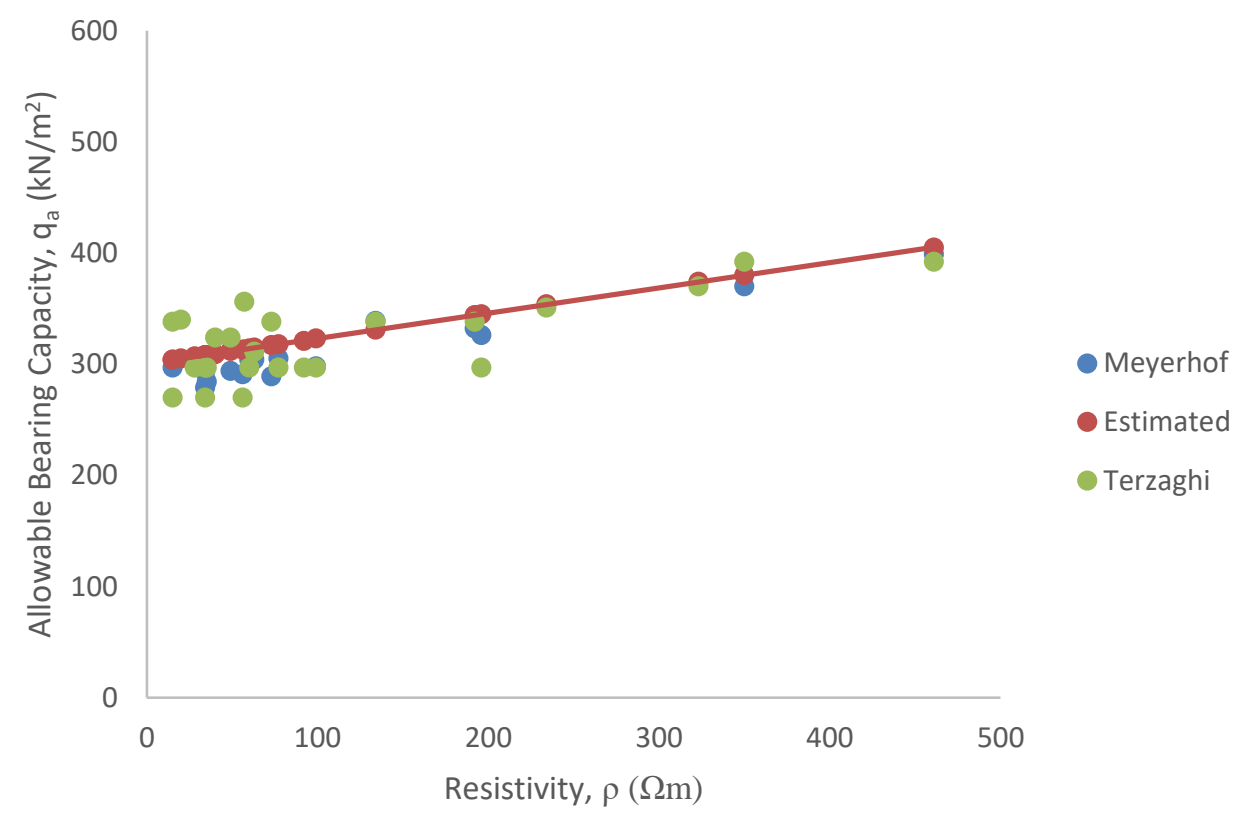

Figure 6: Comparison of allowable bearing pressure estimated from soil resistivity vs. cone resistance plot with allowable bearing capacity computed with Terzaghi and Meyerhof formulae

For all purposes, allowable bearing pressure ( $\mathrm{q}_{\mathrm{a}}$ ) is equal to unconfined compressive strength (UCS) which is twice the undrained shear strength (Oh and Vanapalli, 2018). Unconfined compressive strength (UCS) is the maximum axial compressive stress that a right-cylindrical sample of material can withstand under unconfined conditions (i.e. when confining pressure is zero). The shear strength of soil is the maximum allowable load which can be applied on it (Rémai, 2013) while undrained shear strength, $\mathrm{s}_{\mathrm{u}}$ is the shear strength when the soil is sheared at constant volume. It is an essential parameter for foundation designs in cohesive soils (Kim et al., 2016).

The undrained shear strength of soils can be estimated from CPT data by using bearing capacity equations (Otoko et al., 2016; Zein 2017) The estimation for soils of different types and characteristics may, however, require consideration of the effects of factors such as soil type, moisture content and stress history, which influence cone resistance Zein (2017). With good understanding of the local geology and validation of the correlation between soil resistivity and cone resistance, the allowable bearing pressure and/or undrained shear strength can be reliably suitable for geotechnical foundation designs.

\section{Conclusions}

Empirical relationships were established for estimating cone resistance from resistivity of subsoil for preconstruction geotechnical site investigation.

(i) Very strong correlation exists between the measured cone resistance and soil resistivity.

(ii) The values of allowable bearing pressure estimated by using the empirical relations are consistent with those computed from published general formulae.

(iii) Quantitative estimation of cone resistance and soil strength can be made based on the empirical relationship between cone tip resistance and soil resistivity while few complimentary cone penetrometer and laboratory tests will be required at zones of interest with consequent reduction in the duration and cost of site investigation. 
Acknowledgement: The corresponding author grateful appreciates the Tertiary Education Fund (TetFund) for providing the grant to carry out this study.

\section{References}

Adebisi, N. O. and Fatoba, J. O. (2013). Instrumentation for in situ foundation investigation in Lagos, southwest (SW) Nigeria. Journal of Geology and Mining Research, Vol. 5(4), p. 88-96.

Adeoti, L., Adegbola, R. B., Cardoso, F.C., Bello, R., Eniola, P.J. (2016). A combination of electrical resistivity and cone penetration test techniques for subsurface assessment. Scientia Africana, vol. 15, No. 2, p. 1-10.

Adewoyin, O. O., Joshua, E. O., Akinyemi, M. L., Omoje, W. and Joel, E. S. (2017). Application of 2D resistivity imaging and cone penetration test to assess the hazardous effect of near-surface water on foundations in Lagos, Nigeria. IOP Conf. Series: Journal of Physics. Conf. Series 852. Doi.10.1088/1742-6596/852/1/012033, p. 1-6.

Akça, N. (2003). Correlation of SPT-CPT data from the United Arab Emirates. Engineering Geology, 67(3), p. 219-231, DOI: 10.1016/S0013-7952(02)00181-3.

ASTM Standard D3441 (2016). Standard Test Method for Mechanical Cone Penetration Testing of Soils. ASTM International (ASTM), 8p.

Bowles, J.E. (1997). Foundation Analysis and Design, $5^{\text {th }}$ Edition, McGraw-Hill Companies Inc., New York, ISBN 0-07-912247-7 (set), 1207p.

BS 8004: (2015). Code of Practice for Foundations. BSI Standards, 114p.

Coker, J. O., Makinde, V., Akinpelu, A. (2017). Geophysical and Geotechnical Assessment of Subsurface Conditions at the School of Technology, Lagos State Polytechnic, Ikorodu, Lagos, Nigeria. Int. J. Eng. Mod. Technol., 3(1): p. 33- 42.

Cosenza, P., Marmet, E., Rejiba, F. and Cui, Y. (2006). Correlations between geotechnical and electrical data: A case study at Garchy in France. Journal of Applied Geophysics 60, p. 165-178.

Craig, R. F. (2004). Craig's Soil Mechanics, $7^{\text {th }}$ ed., Spon Press, Taylor and Francis Group, London and New York, ISBN 0-203-57441-9, 458p.

Endres, L. A. and Clement, W. P. (1998). Relating Cone Penetrometer Test Information to Geophysical Data: A Case Study. Symposium on the Application of Geophysics to Engineering and Environmental Problems. https://doi.org/10.4133/1.2922515, 11p.

Eslami, A. and Gholami, M. (2006). Analytical Model for the Ultimate Bearing Capacity of Foundations from Cone Resistance. Scientia Iranical, Vol., 13, No. 3, p. 223-233.

Evans, J. D. (1996). Straight forward Statistics for the behavioral Sciences. Pacific Grove, CA. Brooks/Cole Publishing.

Gautam, P. K., Sastry, R. G. and Mondal, S. K. (2007). The Utility of Multi-electrode Resistivity data in Geotechnical Investigations - A Case Study. European Association of Geoscientists \& Engineers Conference Proceedings,20th EEGS Symposium on the Application of Geophysics to Engineering and Environmental Problems, Apr 2007, cp-179-00078. DOI: https://doi.org/10.39 9 7/ 2214-4609pdb.179.0731-737.

Ghose, R and Goudswaard, J. (2004). Integrating S-wave seismic-reflection data and cone-Penetration test data using a multiangle multiscale approach, Geophysics, Vol., 69, No. 2, p. 440-459.

Kearey, P., Brooks, M. and Hill, I. (2002). An Introduction to Geophysical Exploration. Third Edition. Blackwell Science Limited, 262p.

Kim, K. K., Prezzi, M. and Salgado, R. (2006). Interpretation of Cone Penetration Tests in Cohesive Soils. Final Report FMWA/IN/JTRP-2006/22. INDOT Office of Research and Development, Purdue University, West Lafayette, Indiana, 182p. 
LAUTECH Journal of Civil and Environmental Studies

Volume 7, Issue 1; September, 2021

Meyerhof, G. G. (1956). Penetration tests and bearing capacity of cohesionless soils. American Society of Civil Engineers. J. Soil Mech. Found. Eng. Div. 82: p. 1-19.

Mayne, P. W. (2007). Cone Penetration Testing State-of-Practice, National Cooperative Highway Research Program (NCHRP) Project 20-05, Topic 37-14, Washington D.C., http://onlinepubs.trb.org/Onlinepubs/nchrp/nchrp_syn_368.pdf.

Murthy, V. N. S. (2002). Geotechnical Engineering: Principles and Practices of Soil Mechanics and Foundation Engineering. CRC Press, Florida, 1056p.

Oh, W. T. and Vanapalli, S. K. (2018). Undrained Shear Strength of Unsaturated Soils under Zero or Low Confining Pressure in the Vadose Zone. Vadose Zone Journal, DOI:10. 21 36/vzj2 018. 01. 0024, p. 114.

Otoko, G. R., Fabura-Manuel, I, Igwuagu, M. and Edoh, C. (2016). Empirical Cone Factor for Estimation of Undrained Shear Strength. Electronic Journal of Geotechnical Engineering, Vol. 21, Bund. 18, p. 6069-6076.

Oyedele K. F. and Olorode D. O. (2010). Site Investigations of Subsurface Conditions using Electrical Resistivity method and Cone Penetration Test at Medina Estate, Gbagada, Lagos, Nigeria. World Applied Sciences Journal, Vol. 11, No. 9, p. 1097-1104.

Prasetya, I., Faizah, Y., Sophian, R. I. and Hirnawan, F. (2017). Cone Penetration Test for Bearing Capacity Estimation and Soil Profiling, Case Study: Conveyor Belt Construction in a Coal Mining Concession Area in Loa Duri, East Kalimantan, Indonesia. Proceedings of the $2^{\text {nd }}$ Joint Conference of Utsunomiya University and Universitas Padjadjaran, p. 177-183.

Rahaman, M. A. (1989). Review of the Geology of Southwestern Nigeria, in, Geology of Nigeria, (Kogbe, C. A., Ed.). Rock View (Nig. Ltd.), Jos, Nigeria, p. 41-57.

Rémai, Z. (2013). Correlation of undrained shear strength and CPT resistance. Periodical Poly- technica Civil Engineering 57(1), p. 39-44.

Robertson P. K., and K. L. Cabal. (2010). Guide to Cone Penetration Testing for Geotechnical Engineering, 3rd edition, Gregg Drilling and Testing, Signal Hill, California. 115p.

Rogers, J. D. (2006). Subsurface exploration using the standard penetration test and the cone penetrometer test. Environmental and Engineering Geosciences. Vol. XII, No. 2. p. 161-179.

Sharma, P. V. (2000). Environmental and Engineering Geophysics. Cambridge University Press, UK. 475p.

Terzaghi, K. and Peck, R.B. (1967). Soil Mechanics in Engineering Practice, $2^{\text {nd }}$ Edition John Wiley and Sons, New York, 729p.

Waheed, M. Q. and Asmael, N. M. (2018). Parametric Study of Shallow Foundation Bearing Capacity in Clayey Soil. International Journal of Civil Engineering and Technology, Vol. 9, Issue 10, p. 12231230.

Yi, F. (2014). Estimating soil fines content from CPT data. $3^{\text {rd }}$ International Symposium on Cone Penetration Testing (May 12-14, 2014) - Las Vegas, Nevada.

Vander-Velpen B. P. A. (2004). WinRESIST Version 1.0. Resistivity Depth Sounding Interpreta- tion Software, ITC, Delft, the Netherland, 4p. 1-4.

Zein A. M. (2017). Estimation of undrained shear strength of fine-grained soil from cone pene- tration test. International Journal of Geo-Engineering. DOI 10.1186/s40703-017-0046-y, p. 1-13. 